\title{
Obstetric and perinatal outcome in previous one cesarean section
}

\author{
Seema Patel*, Vijay Kansara, Riddhi Patel, Nikhil Anand
}

Department of Obstetrics and Gynecology, GMERS Medical Collage, Sola, Ahmedabad, Gujarat, India

Received: 18 July 2016

Accepted: 09 August 2016

*Correspondence:

Dr. Seema Patel,

E-mail: drkalpesh1974@yahoo.com

Copyright: ( ) the author(s), publisher and licensee Medip Academy. This is an open-access article distributed under the terms of the Creative Commons Attribution Non-Commercial License, which permits unrestricted non-commercial use, distribution, and reproduction in any medium, provided the original work is properly cited.

\section{ABSTRACT}

Background: Women with previous cesarean sections constitute a high risk group in obstetrics, with associated complications. The cesarean section carries 3 fold risk of mortality compared with vaginal deliveries. The study was conducted to determine the mode of deliveries after previous one cesarean section, maternal and fetal complication.

Methods: This is a prospective observation study. Total 150 patients of previous one caesarean with gestational weeks between 37 to 40 weeks admitted in labour room of Obstetrics and Gynecology Department in Sola Civil Hospital with spontaneous onset of labour, over a period of one year from April 2014 to April 2015 or till the desired sample will reached.

Results: In the present study, out of 150 pregnant women with history of previous one LSCS who were subjected to this study, 39(26\%) underwent elective LSCS, commonest indication being previous pregnancy bad experience $(38.46 \%) .111(74 \%)$ underwent trial of labour after cesarean section out of it 77(69.36\%) had successful VBAC and $34(30.63 \%)$ underwent repeat emergency LSCS. Maternal complications were higher in Emergency LSCS group than in those had a successful VBAC (17.64\% vs.3.89\%)). Neonatal complications were also higher in Emergency LSCS group than in those had a successful VBAC $(2.95 \%$ vs. $0 \%)$.

Conclusions: With proper case selection, appropriate timing and close supervision trial of labour after prior LSCS is safe and often successful.

Keywords: LSCS, TOLAC, VBAC

\section{INTRODUCTION}

Incidence of primary cesarean section has increased multifold over the last 20 years. As a result, an increasing number of women face the issue of mode of delivery in their subsequent pregnancy. ${ }^{1-3}$ The cesarean section epidemic is a reason for immediate concern and deserves serious international attention. ${ }^{4}$ Before 1970's the phrase "once a cesarean, always a cesarean" dictated obstetric practice.

The introduction of Lower segment cesarean section (LSCS) gave a good and strong scar to the uterus to hold and safely deliver a subsequent pregnancy. It is now safe to say "once a cesarean section, always a hospital delivery. ${ }^{4}$
An appropriate clinical setting and properly selected group of women, vaginal delivery after cesarean section (VBAC) is safe and effective. A trial of VBAC is considered safer than a routine cesarean section. ${ }^{4} \mathrm{VBAC}$ offers distinct advantage over a repeat cesarean section since the operative risks are completely eliminated, the hospital stay is much shorter and expenses involved is much less. Both attempting vaginal birth and opting for an elective repeat cesarean section are associated with different risk for the mother and newborn and deciding a delivery plan involves a difficulty weighing of those case. ${ }^{5}$ The main aim of our study was to determine the outcome of pregnancy in women with prior cesarean section in relation to mode of delivery, maternal and perinatal complications. 


\section{METHODS}

A prospective observation hospital based study was carried out in the Department of Obstetrics and gynecology of GMERS medical college / hospital Sola, Ahmedabad; over a period of March 2014 to June 2015. The study was proposed to be of 150 patient of previous one caesarean with gestational weeks between 37 to 40 weeks admitted in labour room of Obstetrics and Gynecology Department in Sola Civil Hospital with spontaneous onset of labour over a period of one year from April 2014 to April 2015.

Inclusion criteria were one prior LSCS, single live fetus, gestation age between 37 to 40 weeks, cephalic presentation. Exclusion criteria were less than 37 weeks and More than 40 weeks of gestation, absolute indication of cesarean section, multiple gestation, and previous complicated caesarean based on antenatal records.

On admission thorough antenatal history was taken and antenatal records were evaluated followed by obstetric examination. A written informed consent had taken from all the cases. All patients were given patient's information sheet before taking consent.

Labour was monitored by partogram. If patient in latent phase (which calculated from admission to the labour room), we waited till 8 hours as per partogram.

Termination of vaginal birth trial based on partogram or if signs of fetal distress, suspected scar dehiscence/rupture based on clinical examination, nonspecific maternal tachycardia and scar tenderness, non-progress of labour defined as $<1 / 2 \mathrm{~cm}$ dilatation of cervix per hour, assessed over 4 hour.

In second stage of labour, prophylactic forceps or vacuum applied if second stage exceeds 30 minutes. Active management of third stage of labour given to each pregnant woman (AMTSL) as per WHO guidelines. Any postpartum complications recorded. Neonatal assessment done by weight of neonate, APGAR score at 1 and 5 minutes, need of resuscitation, NICU admission.

Maternal outcomes were measured in terms of type of delivery (VBAC, ERCS, and Failed VBAC), occurrence of scar dehiscence, PPH with need for blood transfusion, uterine rupture, adherent placenta and hysterectomy. Perinatal outcome measured includes incidence of RDS, NICU admission and perinatal mortality.

All selected outcome variables were recorded and datas were analysed. Chi square test was applied for statistical analysis of Qualitative data. In some table, when cell value was $<5$, Chi square value was given with YATES correction. $\mathrm{P}<0.05$ - Statistically significant for comparison of two samples mean, two tailed $\mathrm{Z}$ test was used for identification of significance in quantitative data. Statistically analysis was performed by using analytical tool pack of Microsoft excel - 2010 and 2007.

\section{RESULTS}

In the present study, 150 patients of previous one LSCS between gestational weeks of 37 to 40 weeks were included. Out of 150 patients, 111 patients gave consent for TOLAC while 39 patients refused TOLAC.

From 111 patients, 77 patients had successful VBAC while 34 patients had failed TOLAC (EME CS). So these two groups are compared with different parameters.

In the present study out of 111 patients, maximum number of patients with successful VBAC (80.5\%) was found in age group of 21-30 yrs. With the increasing age chances of VBAC were decreased while chances of emergency cesarean section rate were increased $(\mathrm{P}=0.26$, Not significant).

Table 1: Age distribution according to TOLAC outcome.

\begin{tabular}{|c|c|c|c|c|}
\hline Age in years & Group A (77) & Group B (34) & $\chi^{2}($ chi square value $)$ & P value \\
\hline $21-30$ & $64(80.51 \%)$ & $31(88.23 \%)$ & \multirow{3}{*}{1.51} & \multirow{3}{*}{0.26} \\
\hline $31-40$ & $13(16.88 \%)$ & $3(8.82 \%)$ & & \\
\hline Mean age & 26.59 & 26.08 & & \\
\hline
\end{tabular}

Table 2: Gestational age distribution according to TOLAC outcome.

\begin{tabular}{|lll|}
\hline Gestational age & Successful VBAC (77) & Failed TOLAC (EMIE CS) (34) \\
\hline $37.1-38$ & $35(45.45 \%)$ & $15(44.11 \%)$ \\
\hline $38.1-39$ & $25(32.46 \%)$ & $9(26.47 \%)$ \\
\hline $39.1-40$ & $17(22.07 \%)$ & $10(29.41 \%)$ \\
\hline
\end{tabular}


Table 3: Obstetric history according to TOLAC outcome.

\begin{tabular}{|lllll|}
\hline Obstetric history (Gravida) & Group A (77) & Group B (34) & $\chi^{2}$ (chi square value) & P value \\
\cline { 1 - 3 } & $49(63.63 \%)$ & $28(76.47 \%)$ & 3.88 & 0.04 \\
\hline
\end{tabular}

Table 4: History of Prior vaginal delivery according to TOLAC outcome.

\begin{tabular}{|llll|c|}
\hline Prior vaginal delivery & Group A(77) & Group B (34) & $x^{2}$ (chi square value) & P value \\
\hline Present & $28(36.36 \%)$ & $6(17.64 \%)$ & 3.88 & 0.04 \\
\hline Absent & $49(63.63 \%)$ & $28(82.35 \%)$ & & \\
\hline
\end{tabular}

In the present study, Gestational age by scan of the patient studied varied from 37 to 40 weeks. Maximum number of the VBAC patients was seen in between the ages of 37.1-38 weeks accounting for $45.45 \%$. The average gestational weeks of the patient in the study was $38.48 \pm 0.82$ (95\% CL: 37.66 to 39.3 ) for VBAC.

In the present study, $36.3 \%$ patients of VBAC had more than 3 obstetric history compared to failed TOLAC patient $(23.5 \%)$. So increased parity was strongly associated with successful VBAC $(P=0.04$, Significant).

In the present study, $36.36 \%$ patients of Group A had history of prior vaginal delivery compared to $17.64 \%$ of Group B patients. History of prior vaginal delivery had significant correlation with successful VBAC. $(\mathrm{P}=0.04$, Significant).

Table 5: Duration between the previous CS and the current pregnancy according to TOLAC outcome.

\begin{tabular}{|c|c|c|c|c|}
\hline $\begin{array}{l}\text { Duration between the previous CS } \\
\text { and the current pregnancy }\end{array}$ & Group A(77) & Group B (34) & $\chi^{2}($ chi square value $)$ & P value \\
\hline$<18$ month & $7(9.09 \%)$ & $7(20.58 \%)$ & \multirow{2}{*}{2.82} & \multirow{2}{*}{0.09} \\
\hline$>18$ month & $70(90.9 \%)$ & $27(79.41 \%)$ & & \\
\hline
\end{tabular}

Table 6: Indication of emergency cesarean section (Failed TOLAC).

\begin{tabular}{|lll|}
\hline $\begin{array}{l}\text { Indication of } \\
\text { emergency cesarean }\end{array}$ & $\begin{array}{l}\text { No. of } \\
\text { patients }\end{array}$ & Percentage (\%) \\
\hline $\begin{array}{l}\text { Failure to progress of } \\
\text { labour }\end{array}$ & 15 & 44.12 \\
\hline Fetal distress & 7 & 20.58 \\
\hline Scar tenderness & 11 & 32.35 \\
\hline $\begin{array}{l}\text { Prolonged latent phase } \\
\text { with scar tenderness }\end{array}$ & 1 & 2.95 \\
\hline
\end{tabular}

In the present study, $90.9 \%$ patients of VBAC had interval between previous cesarean and current pregnancy more than 18 months. While $9.09 \%$ patients of successful VBAC had duration less than 18 months $(P=0.09$, Not Significant).

In the present study, most common indication of emergency cesarean section was Failure to progress of labour $(44.12 \%)$ and scar tenderness $(32.35 \%)$. The other indication were include fetal distress (20.5\%) and prolonged latent phase with scar tenderness $(2.95 \%)$.
Table 7: Intraoperative finding in Emergency Cesarean Section (Failed TOLAC).

\begin{tabular}{|lll|}
\hline Intraoperative finding & $\begin{array}{l}\text { EME CS } \\
\text { (failed } \\
\text { TOLAC) }\end{array}$ & $\begin{array}{l}\text { ERCS } \\
\text { (refused } \\
\text { TOLAC) }\end{array}$ \\
\hline Scar rupture & $1(2.9 \%)$ & - \\
\hline Cord around neck & $7(20.58 \%)$ & $4(10.25 \%)$ \\
\hline MSL & $7(23.48 \%)$ & $2(5.12 \%)$ \\
\hline $\begin{array}{l}\text { Lower segment thinned } \\
\text { out(<4 mm) }\end{array}$ & $5(11.76 \%)$ & $6(15.38 \%)$ \\
\hline Scar dehiscence & $8(23.52 \%)$ & - \\
\hline Deflexed head & $2(5.88 \%)$ & - \\
\hline $\begin{array}{l}\text { Dense adhesion over } \\
\text { anterior wall of uterus }\end{array}$ & $2(5.88 \%)$ & $2(5.12 \%)$ \\
\hline $\begin{array}{l}\text { Occipito transverse } \\
\text { position }\end{array}$ & $1(2.9 \%)$ & - \\
\hline $\begin{array}{l}\text { Occipito posterior } \\
\text { position }\end{array}$ & $1(2.9 \%)$ & - \\
\hline
\end{tabular}


Table 8: Maternal Complication in studied groups.

\begin{tabular}{|lllll|}
\hline Maternal postnatal problem & TOLAC (111) & Refusing TOLAC & P value \\
\cline { 1 - 5 } & Group A(77) & Group B (34) & Total (111) & (39) (ERCS) \\
\hline Uterine rupture & 0 & $1(2.94 \%)$ & $1(0.9 \%)$ & - \\
\hline Vaginal hematoma & - & $1(2.94 \%)$ & $1(0.9 \%)$ & - \\
\hline Third degree perineal tear & $2(2.59 \%)$ & - & $2(1.8 \%)$ & - \\
\hline Extension of scar & $1(1.29 \%)$ & - & $1(0.9 \%)$ & - \\
\hline Total & - & $4(11.76 \%)$ & $4(3.6 \%)$ & $2(5.12 \%)$ \\
\hline
\end{tabular}

Table 9: Birth weight in TOLAC.

\begin{tabular}{|c|c|c|c|c|}
\hline $\begin{array}{l}\text { Birth } \\
\text { weight(Kg) }\end{array}$ & Group A (77) & Group B (34) & $\begin{array}{l}x^{2} \text { (chi square } \\
\text { value) }\end{array}$ & $P$ value \\
\hline$<3.5$ & $74(96.10 \%)$ & $34(100 \%)$ & \multirow{2}{*}{2.3} & \multirow{2}{*}{0.24} \\
\hline$\geq 3.5$ & $3(3.89 \%)$ & $0(0 \%)$ & & \\
\hline
\end{tabular}

Table 10: Perinatal outcome according studied groups.

\begin{tabular}{|c|c|c|c|c|c|}
\hline \multirow[b]{2}{*}{ Perinatal outcome } & \multicolumn{3}{|l|}{ TOLAC (111) } & \multirow{2}{*}{$\begin{array}{l}\text { Refusing } \\
\text { TOLAC (39) } \\
\text { (ERCS) }\end{array}$} & \multirow[b]{2}{*}{$P$ value } \\
\hline & Group A (77) & Group B (34) & Total (111) & & \\
\hline $\begin{array}{l}\text { APGAR score at } 5 \min (>6) \\
\text { (healthy) }\end{array}$ & $74(96.1 \%)$ & $27(79.41 \%)$ & $101(90.9 \%)$ & $38(97.43 \%)$ & \multirow{3}{*}{0.1} \\
\hline NICU admission & $3(3.89 \%)$ & $6(17.64 \%)$ & $9(8.10 \%)$ & $1(2.56 \%)$ & \\
\hline Perinatal mortality & $0(0 \%)$ & $1(2.95 \%)$ & $1(0.9 \%)$ & - & \\
\hline
\end{tabular}

Table 11: Reason for refusal of consent.

\begin{tabular}{|lll|}
\hline $\begin{array}{l}\text { Reason for } \\
\text { refusal }\end{array}$ & $\begin{array}{l}\text { No. of patients } \\
(39)\end{array}$ & $\begin{array}{l}\text { Percentage } \\
(\%)\end{array}$ \\
\hline $\begin{array}{l}\text { Previous } \\
\text { pregnancy bad } \\
\text { experience }\end{array}$ & 15 & 38.46 \\
\hline $\begin{array}{l}\text { Secondary } \\
\text { infertility }\end{array}$ & 8 & 20.51 \\
\hline $\begin{array}{l}\text { Small family } \\
\text { norms and not } \\
\text { taking risk }\end{array}$ & 12 & 30.76 \\
\hline $\begin{array}{l}\text { Not single } \\
\text { living baby }\end{array}$ & 4 & 10.25 \\
\hline
\end{tabular}

In the present study, Intra operative Scar dehiscence was significant finding in 8 patients $(23.52 \%)$ of scar tenderness. The second most common intra operative finding in present study was Thick MSL (23.48\%) which was positive finding in fetal distress. Lower segment thickness $<4 \mathrm{~mm}$ was found in 4 patients $(11.76 \%)$. The other significant intra operative finding that may lead to failed TOLAC were Cord around neck (20.48\%), Deflexed head $(5.88 \%)$, Dense adhesion over anterior wall of uterus $(5.88 \%)$, abnormal position of vertex $(5.8 \%)$. Scar rupture was found in only one patient who had scar tenderness and maternal tachycardia. There were significant intra operative finding present in ERCS also like lower segment thinned out $(15.38 \%)$, MSL $(5.12 \%)$, Cord around neck $(10.25 \%)$ and dense adhesion on LUS $(5.12 \%)$.

In the present study, maternal complication was slightly higher in TOLAC compared to refusing TOLAC. Complication like PPH (2.94\% v/s 0\%), uterine rupture $(2.94 \% \mathrm{v} / \mathrm{s}$ 0\%) was higher in Group B compared to refusing TOLAC. Complications like vaginal hematoma $(2.59 \% \mathrm{v} / \mathrm{s} 0 \%)$ and third degree perineal tear $(1.29 \% \mathrm{v} / \mathrm{s}$ $0 \%$ ) were higher in Group A compared to refusing TOLAC. While extension of scar $(3.6 \% \mathrm{v} / \mathrm{s} 5.12 \%)$ was in refusing TOLAC (ERCS) compared to TOLAC patients. So chances of maternal complications were higher in Group B compared to ERCS but in Group A complications were lower than refusing TOLAC patients (elective repeat cesarean section). There was no statistically significant relation of maternal complication between TOLAC and refusing TOLAC (ERCS) patient $(\mathrm{P}=0.5$, using Chi square test $)$.

In the present study, there was no such difference of baby birth weight related to outcome. $96.1 \%$ patients of Group 
A had birth weight less than $3.5 \mathrm{~kg}$ compared to Group B (100\%). Mean birth weight of baby for Group A was 2.75 $\mathrm{Kg}(95 \%$ CI 2.40 to 3.06) and for Group B was $2.78 \mathrm{~kg}$ (95\% CI 2.50 to 3.08). Successful VBAC was not associated with birth weight of baby. (Chi square value was 2.3 with YATES correction $=0.24$, Not Significant)

In the present study, perinatal morbidity was $8.10 \%$ in TOLAC compared to $2.56 \%$ in refusing TOLAC patient. Perinatal mortality (2.95\% vs. $0 \%$ ) and NICU admission (17.64\% vs. $3.89 \%)$ were higher in Group B compared to Group A. NICU admission rate was $3.89 \%$ in Group A because of prolonged labour and instrumental deliveries. So perinatal outcome was significant in emergency cesarean after failed TOLAC. One baby was expired in Group B due to rupture uterus. So perinatal morbidity and mortality were increase in TOLAC compared to refusing TOLAC but it was comparable between ERCS and successful VBAC patient. In the present study, there was no significant difference between perinatal outcome between TOLAC and refusing TOLAC patient $(\mathrm{P}=0.1$, by Chi square test).

In the present study, $38.46 \%$ of ERCS (elective repeat cesarean section) patients refused TOLAC for previous pregnancy bad experience reason. $30.76 \%$ patient had small family norms so that they would not took any risk and refused for TOLAC. $20.51 \%$ patient had secondary infertility so they opt for ERCS. $10.25 \%$ had bad obstetric history and recurrent pregnancy loss. So because of varied reason 39 patients in our study refused TOLAC.

In the present study, $36.36 \%$ patients of VBAC had history of prior vaginal delivery compared to $17.64 \%$ of failed TOLAC patients. History of prior vaginal delivery had significant correlation with successful VBAC.

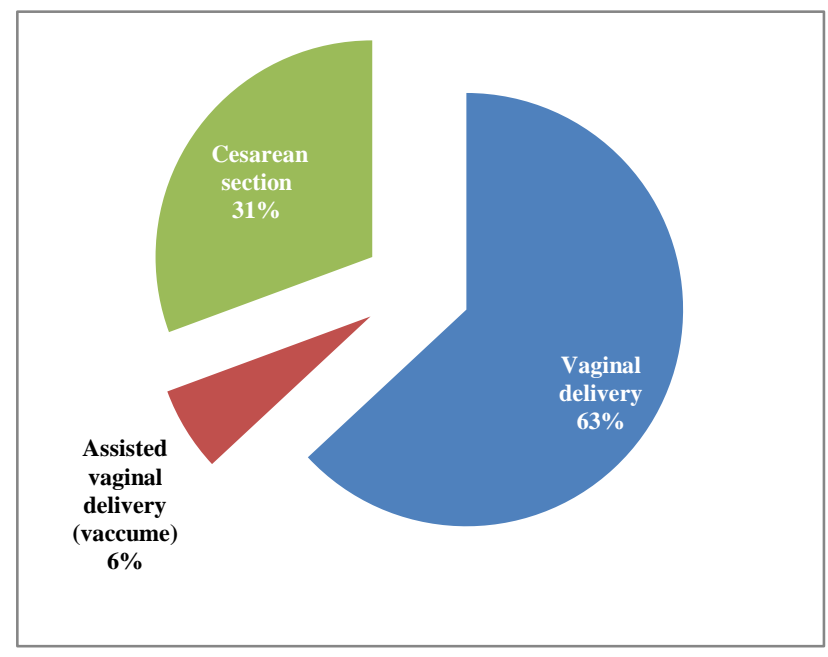

Figure 1: Mode of present delivery in TOLAC.

\section{DISCUSSION}

Women with previous one LSCS require special management, both antenatally and in labor. The decision for a trial of labor or the elective repeat LSCS is an individual one that should be based on careful selection and thorough counselling. ${ }^{6}$ Several studies suggest that for appropriately selected cases with previous one LSCS, a trial for vaginal delivery is safe. Published literature shows that there has been a $60-80 \%$ success in VBAC. ${ }^{4,6,7}$ Our success rate is $(74 \%)$ is comparable to these studies. VBAC success were comparable to the studies of OC Ezechi et al (2005), Tripathi JB et al (2006), Bhat BPR et al, Kumar P et al. ${ }^{7-10}$

The most common indication for the ERCS in our study was previous pregnancy bad experience $(38.46 \%)$. In our study ,34 cases underwent emergency LSCS, most common indication of emergency cesarean section was Failure to progress of labour $(44.12 \%)$ and scar tenderness $(32.35 \%)$. The other indication were include fetal distress $(20.5 \%)$ and prolonged latent phase with scar tenderness $(2.95 \%)$. There is a consistent evidence to show that a prior vaginal delivery is associated with a higher rate of successful trial of labor compared with patients with no prior vaginal delivery. Our results are comparable with reported studies of Landon et al, Shah Jitesh Mafatlal et al neither repeat caesarean delivery nor trial of labor is risk free. ${ }^{13,15}$ Maternal morbidity in terms of atomic PPH, need for blood transfusion, cervical and vaginal tear, traumatic PPH and uterine scar problems are more common with trial of vaginal delivery. Incidence of complication in caesarean group was $17.63 \%$ in our study compared to $3.89 \%$ in VBAC group. The difference in maternal morbidity rate is not statistically significant in studies of Shah SR et al, Dodd J et al, and Mozurkewich EL et al. ${ }^{6,16,17}$

Most of the neonates, who were delivered by emergency caesarean section, were taken to NICU for observation, as most of the emergency caesarean sections were done in view of failure to progress and fetal distress. Our study was well comparable with studies of Shah Jitesh et al and Shruthi s Goel et al who concluded that infants born after successful VBAC had the lowest rates of NICU admission and those born by failed VBAC had highest NICU admission. ${ }^{13,14}$

\section{CONCLUSION}

With proper case selection, appropriate timing and close supervision trial of labour after prior LSCS is safe and often successful. A prior vaginal delivery, particularly a prior VBAC are associated with a higher rate of success compared to patient with no prior vaginal delivery.

\section{ACKNOWLEDGEMENTS}

Authors would like to thanks Dr. Ajesh Desai, H.O.D. Department of Obstetrics and Gynecology, GMERS Medical Collage, Sola, Ahmedabad, Gujarat, India 
Funding: No funding sources

Conflict of interest: None declared

Ethical approval: Not Required

\section{REFERENCES}

1. Curtin SC. Rates of caesarean birth and VBAC, 1991-95.Monthly vital Statistics report; 45(11) Suppl 3 Hyattsville (MD). National center for Health statistics; 1997.

2. Rates of caesarean delivery. United States, 1991MMWR Morb Mortal Wkly Rep. 1993;42:285-9.

3. Stafford RS. Alternative strategies for controlling rising caesarean section rates. JAMA 1990;263:6837.

4. Mukherjee SN. Rising cesarean section rate. J Obstet Gynecol India 2006; 56:298-300.

5. Cunningham FG, Bangdiwala SI, Brown SS. NIH consensus development conference statement on vaginal birth after cesarean: new insights.Obstet Gynecol.2010;115:1279-95.

6. Shah SR, Prasad P. Outcome of labour in previous one lower segment cesarean section cases. Asian J Obstet Gynecol Pract. 2006;10:7-11.

7. Tripathi JB, Doshi HU. Pattern of cervical dilatation in women with a previous cesarean section, J Obstet Gynaecol India. 2005;55:125-7.

8. Ezechi OC, Kalu BKE, Njokanma FO, Ndububa V, Nwokoro CA. Trial of labour after a previous caesarean section delivery: a private hospital experience. Ann African Med. 2005;4:113-7.

9. Bhat BPR, Savant R, Kamath A. Outcome of a post caesarean pregnancy in a tertiary center of a developing country. J ClinDiagn Res. 2010;3:20059 .
10. Kumar P, Shivkumar PV, Jaiswal A, Kumar N, Saharan K. Subjetive assessment of LSCS scar site for vaginal birth after caesarean trial and outcome in MGIMS, Sewagram, Wardha, India. Int J Biol Med Res. 2012;3:1825-9.

11. Vardhan S, Behera RC, Sandhu GS, Singh A, Bandhu HC. Vaginal birth after caesarean section: analysis of indicators of success. J Indian Med Assoc. 2006;104:113-5.

12. Begum I, Khan A, Khan S, Begum S. Caesarean and Post-Partum Hystrectomy. Pak J Med Res. 2004;43:134-7.

13. Shah JM, Mehta MN. Analysis of mode delivery in women with previous one caesarean section. J Obstet Gynecol India. 2009;59:136-9.

14. Goel SS. Outcome of post caesarean pregnancy and comparison of maternal and foetal outcome following vaginal birth versus repeat caesarean section in a rural hospital. Int $\mathrm{J}$ Reprod Contracept Obstet Gynecol. 2013;2(1):16-22 .

15. Landon MB, Leindecker S. The MFMU caesarean registry: factors affecting the success of trial of labour after previous caesarean. Am J Obstet Gynecol. 2005;193:1016-23.

16. Dodd J, Crowther C. Vaginal birth after caesarean versus elective repeat caesarean for women with a single prior caesarean birth: a systemic review of literature. Aust NZJ Obstet Gynaecol. 2004;44:38791.

17. Mozurkewich EL, Hutton EK. Elective repeat caesarean delivery versus trial of labour: a metaanalysis of the literature from 1989 to 1999 . Am J Obstet Gynecol. 2000;183:1187-97.

Cite this article as: Patel $\mathrm{S}$, Kansara V, Patel $\mathrm{R}$, Anand N. Obstetric and perinatal outcome in previous one cesarean section. Int $\mathrm{J}$ Reprod Contracept Obstet Gynecol 2016;5:3141-6. 